
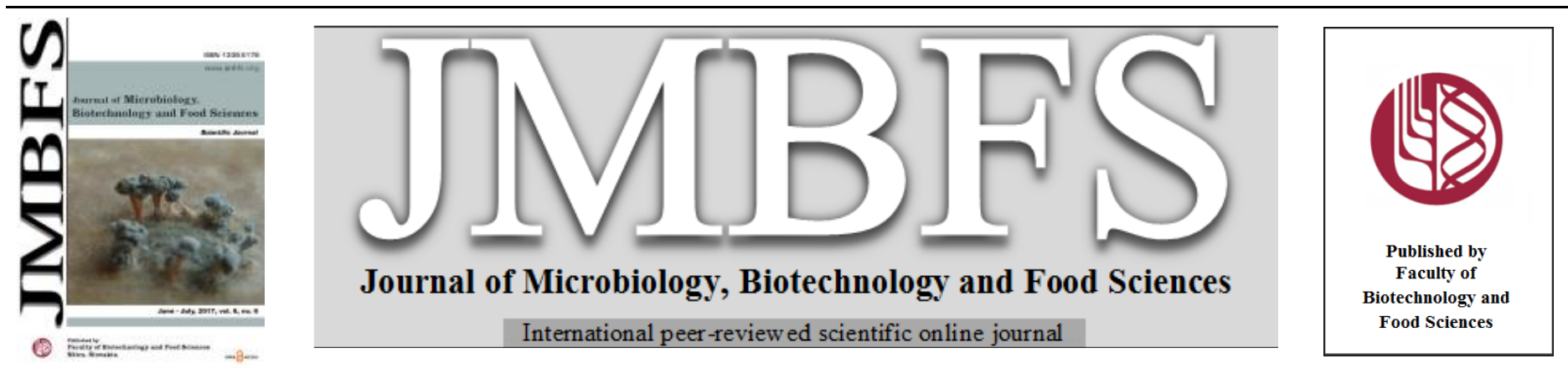

\title{
THE CONTENT OF POLYPHENOLS AND CHOSEN HEAVY METALS IN CHICKPEA SEEDS (CICER ARIETINUM L.) AFTER MICRONUTRIENTS APPLICATION INTO SOIL
}

\section{Mária Timoracká* and Alena Vollmannová}

\author{
Address(es): Ing. Mária Timoracká, $\mathrm{PhD}$., \\ Slovak University of Agriculture in Nitra, Faculty of Biotechnology and Food Sciences, Department of Chemistry, Tr. A. Hlinku 2, 94901 Nitra, Slovak Republic, \\ phone number: +421 376414862 .
}

*Corresponding author: maria.timoracka@uniag.sk

doi: 10.15414/jmbfs.2017.6.6.1246-1249

\section{ARTICLE INFO}

Received 9. 3. 2017

Revised 29. 4. 2017

Accepted 10. 5. 2017

Published 1. 6. 2017

Regular article

OPEN $\partial_{\text {AcCESS }}$

\section{ABSTRACT}

The aim of work was the investigation of the input of chosen heavy metals into chickpea and polyphenols accumulation in seeds cultivated after $\mathrm{Zn}$ and $\mathrm{Cu}$ application into soil in model conditions. The soil used in the pot trial was uncontaminated. Chickpea (cv. Slovák) was harvested in full ripeness. With increased $\mathrm{Zn}(\mathrm{Cu})$ doses applied into the soil (0-500 and 0-100 mg.kg ${ }^{-1}$ for $\mathrm{Zn}$ and $\mathrm{Cu}$, respectively), the strong statistical positive relationship between soil $\mathrm{Zn}(\mathrm{Cu})$ content and $\mathrm{Zn}(\mathrm{Cu})$ amount in seeds of chickpea was confirmed. Despite of high $\mathrm{Zn}(\mathrm{Cu})$ doses applied into the soil in model conditions, in all variants the determined $\mathrm{Zn}$ and $\mathrm{Cu}$ amount in chickpea was below the maximal allowed content in foodstuffs. Chickpea cv. Slovák accumulated high amounts of $\mathrm{Pb}$ and $\mathrm{Cd}$ (in all variants higher than hygienic limits). The contents of other tested heavy metals $(\mathrm{Zn}, \mathrm{Cu}, \mathrm{Ni}, \mathrm{Cr}$ ) were lower than hygienic limits. With increased $\mathrm{Zn}$ doses applied into the soil the polyphenols contents determined in seeds of chickpea were increased. With increased $\mathrm{Cu}$ doses applied into the soil the polyphenols contents determined in seeds of chickpea were decreased. The strong statistical relationship between soil $\mathrm{Zn}$ content and polyphenols amount $(\mathrm{R}=0.911)$ as well as the antioxidant capacity values $(\mathrm{R}=0.992)$ was confirmed. The moderate statistical linear negative relationship between soil $\mathrm{Cu}$ content and polyphenols content $(\mathrm{R}=-0.671)$ and increased antioxidant capacity values in seeds of chickpea was confirmed.

Keywords: chickpea, metal contamination, zinc, copper

\section{INTRODUCTION}

Chickpea (Cicer arietinum L.) is an annual grain legume that is extensively cultivated for human consumption. Chickpea is a good source of carbohydrates (low glycaemic index) and protein, together constituting about $80 \%$ of the total dry seed mass (Chibbar et al., 2010) in comparison to other pulses. Chickpea also contains important minerals (i.e. $\mathrm{Ca}, \mathrm{Mg}, \mathrm{Zn}, \mathrm{K}, \mathrm{Fe}$ and $\mathrm{P}$ ) and vitamins (i.e. thiamine and niacin) (Zia-Ul-Haq et $\boldsymbol{a l}$., 2007), and is relatively free from antinutritional factors (Muzquiz, Wood, 2007). Chickpea, similar to other legume seeds, must be soaked and/or cooked before consumption, a procedure that improves the flavor and palatability of the food product and increases its nutritional bioavailability by inactivaving antinutritional factors (Chau et al. 1997). Seeds of chickpea are helpful source of zinc and folate. Zinc is the main micronutrient in the soil that limits chickpea productivity (Ahlawat et al., 2007). In general, each tonne of chickpea grain removes $38 \mathrm{~g}$ of $\mathrm{Zn}$ from the soil (Ahlawat et al., 2007). Among micronutrients, $\mathrm{Zn}$ deficiency is perhaps the most widespread (Roy et al., 2006) and is common among chickpea-growing regions of the world.

The antioxidant capacity and antiproliferative effects of legumes are associated with the presence of phenolic compounds (Dong et al., 2007). Phenolic cpmpounds are known to exhibit a range of biological activities, including antibacterial, antioxidant and antiinflammatory properties (Kamatou et al., 2010). In studies with chickpea it was found that isolated hulls from a colored chickpea line contain large amounts of polyphenols and flavonoid compounds that exhibit high levels of antioxidant activity (Segev et al., 2010). On the other hand, common chickpea varieties with beige-colored seeds have low levels of total phenolic content, total flavonoid content and antioxidant activity determined by ferric reducing ability of the plasma (Segev et al., 2010). This variation in both seed coat color and antioxidant activity maked colored chickpea a strong potential model for studies of functional foods. Chickpea also contains isoflavones such as daidzein and genistein. In addition, high levels of genistein hexoside were detected recently in raw chickpea flours (Aguilera et al., 2011).

In our work, chosen micronutrients zinc and copper were added to the soil to reduce the intake of other heavy metals, especially of $\mathrm{Cd}$ or $\mathrm{Pb}$ - these toxic metals are present in the soil above the hygienic limit on most territory of the Slovak Republic - as well as to its consecutive accumulation in chickpea seeds and influence on total polyphenols creation and antioxidant activity of chickpea.

\section{MATERIALS AND METHODS}

\section{Plant material}

The cultivar of chickpea (Cicer arietinum L.) (cv. Slovak) was harvested in full ripeness and obtained from the Research Centre of Plant Production in Piešt'any (Slovakia).

\section{Soils samples}

In the pot experiments the soil from locality Cakajovce (Slovak village located near to Nitra) was used. The soil was characterized by low supply of humus and the neutral soil reaction suitable for the legume cultivation. The used soil was characterized also by high content of potassium and phosphorus as well as by a very high content of magnesium. The soil used in the pot trial was uncontaminated. Only determined $\mathrm{Cd}$ content was on the level of limit value given by Law $\mathbf{N}^{\mathbf{0}} \mathbf{2 2 0} / \mathbf{2 0 0 4}$ (valid in the Slovak Republic) for the soil extract by aqua regia as well as $\mathrm{Pb}$ content on the level of critical value given by Law $\mathbf{N}^{\circ}$ 220/2004 (valid in the Slovak Republic) for the relationship between soil and plant. The values were far below threshold values proposed.

\section{The experiment}

The experiment was based on four replications in each variant. Five kilograms of soil was thoroughly mixed with a sand $(1 \mathrm{~kg})$ and togheter were submitted into plastic bowl-shaped pots with foraminated bottom (average: $20 \mathrm{~cm}$ and height: 25 $\mathrm{cm})$. The solution of $\mathrm{ZnSO}_{4} \cdot 7 \mathrm{H}_{2} \mathrm{O}$ was added to each pot to correspond to 0 (control, A variant), 40 (B variant), 250 (C variant), and 500 (D variant) $\mathrm{mg}$ Zn.kg ${ }^{-1}$ of soil. 
The solution of $\mathrm{CuSO}_{4} .5 \mathrm{H}_{2} \mathrm{O}$ was added to each pot to correspond to 0 (control,

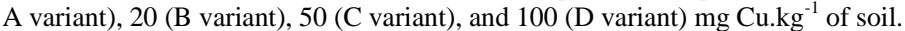
Individual doses were chosen by Decision of the Ministry of Agriculture of Slovak Republic No $531 / 1994-540$ about the maximum exposure levels of risky compounds in the soil - hygienic limit (B variant), half dose of analytically significant contamination (C variant), analytically significant contamination (D variant).

\section{Analytical methods}

The chickpea seeds were decomposited with using of $\mathrm{HNO}_{3}$ by microwave digestion in instrument MARS X-PRESS. The solutions were analyzed by flame AAS (AAS Varian AA Spectr DUO $240 \mathrm{FS} / 240 \mathrm{Z} / \mathrm{UltrAA}$ ). Gained results in mg.kg-1 of dry mater were evaluated according to the Food Codex of the Slovakia valid in the Slovak Republic as well as according to Commission Regulation 1881/2006.

\section{Total polyphenols}

Total polyphenol content (TP) was determined using Folin-Ciocalteau reagent (FCR) according to (Lachman et al., 2003). The solutions were measured at 765 $\mathrm{nm}$ using Shimadzu spectrophotometer (710, Shimadzu, Kyoto, Japan). The total polyphenols content was calculated as gallic acid equivalents (GAE) in milligrams per kilogram of dry matter.

The antioxidant activity (AA) was determined using free radical 2,2-diphenyl-1 picrylhydrazyl (DPPH) according to (Brand-Williams et al., 1995). The solutions were measured at $515 \mathrm{~nm}$ in a Shimadzu spectrophotometer (Shimadzu, Kyoto, Japan). Results were calculated as \% inhibition of DPPH.

Table 1 Heavy metals contents $\left(\mathrm{mg} . \mathrm{kg}^{-1}\right)$ in seeds of chickpea cv. Slovak after $\mathrm{Zn}$ application into soil

\begin{tabular}{|c|c|c|c|c|c|c|}
\hline Var. & $\mathrm{Zn}$ & $\mathrm{Cu}$ & $\mathrm{Ni}$ & $\mathrm{Cr}$ & $\mathrm{Pb}$ & $\mathrm{Cd}$ \\
\hline A & $\frac{31.63}{(1.61)}$ & $\frac{6.43}{(1.38)}$ & $\underline{\underline{0.70}}$ & $\underline{\underline{0.93}}$ & $\frac{2.58}{(0.20)}$ & $\underline{0.19}$ \\
\hline B & 35.60 & $\underline{5.05}$ & $\underline{0.95}$ & $\underline{0.80}$ & $\underline{2.50}$ & $\underline{0.14}$ \\
\hline B & $(0.16)$ & $(\overline{1.76})$ & $(\overline{0.36})$ & $(\overline{0.07})$ & $(\overline{0.08})$ & $(\overline{0.04})$ \\
\hline $\mathrm{C}$ & $\underline{47.85}$ & $\underline{9.65}$ & 1.45 & $\underline{1.10}$ & 3.00 & $\underline{0.14}$ \\
\hline & (3.55) & $\underline{(1.45)}$ & $(0.17)$ & $\underline{(0.14)}$ & $\underline{(0.15)}$ & $(\underline{0.06})$ \\
\hline D & $\frac{49.08}{(0.84)}$ & $\frac{9.15}{(0.57)}$ & $\frac{1.65}{(0.07)}$ & $\frac{0.90}{(0.22)}$ & $\frac{3.00}{(0.22)}$ & $\frac{0.12}{(0.02)}$ \\
\hline Limit & 50.0 & 15.0 & 3.0 & 4.0 & 0.2 & 0.1 \\
\hline Max. & - & - & - & - & 0.2 & 0.1 \\
\hline
\end{tabular}

Legend: The results show the mean value and the standard deviation (in parenthesis). Limit value for legumes according to the Food Codex of the Slovakia was shown. Max. value is maximal residue level according to Commission Regulation 1881/2006.

Wang et al. (2010) determined lower amounts of $\mathrm{Cu}$ and a similar $\mathrm{Zn}$ content in comparison to our results. By Khan et al. (1998) observed also zinc concentration in the shoot tissue of chickpea increased with an increase in $\mathrm{Zn}$ fertilisation and they confirm that low and high moisture regimes had no effect on critical Zn concentration. Rutkowska et al. (2014) reported the concentration of active zinc ions $\left(\mathrm{Zn}^{2+}\right)$ in the soil solution for the most part relies upon soil reaction when compared with other investigated physical and chemical soil properties. Higher $\mathrm{Zn}$ concentration can be projected in the soil solution of acidic soils when compared to soils with neutral soil reaction.

The graded $\mathrm{Cu}$ doses which have been applied to the soil in the model conditions resulted in increased $\mathrm{Cu}$ content in seeds of chickpea harvested in the stage of ful ripeness are presented in Table 2. The strong statistical relationship between $\mathrm{Cu}$

\section{Statistics}

All statistical analyses were carried out using the statistical software Statistica 12.0 (Statsoft, USA). Each analysis was done in six repetitions. Descriptive data analysis included mean, standard deviation. Mean comparisons between heavy metals content were done by the LSD-test, $\mathrm{P}<0.05$.

\section{RESULTS AND DISCUSSION}

Two experiments were realised as the pot trials in the vegetation cage with the aims to investigate the effect of addition of increasing rates of selected micronutrients (zinc, copper) into the soil and its consecutive accumulation in chickpea seeds on total polyphenols and antioxidant activity.

\section{The evaluation of heavy metals content}

The graded $\mathrm{Zn}$ doses applied into the soil in the model conditions resulted in increased $\mathrm{Zn}$ content in seeds of chickpea harvested in the stage of full ripeness are presented in Table 1. The strong statistical relationship between soil $\mathrm{Zn}$ content and $\mathrm{Zn}$ amount in seeds of chickpea was confirmed $(\mathrm{R}=0.889)$. In all variants the $\mathrm{Zn}$ content in seeds of chickpea was lower than hygienic limit. The determined $\mathrm{Pb}$ and $\mathrm{Cd}$ contents in control seeds were higher than maximal allowed amounts given by the legislative (by $1200 \%$ and $90 \%$, respectively). The $\mathrm{Zn}, \mathrm{Cu}, \mathrm{Pb}$ and $\mathrm{Ni}$ contents were increased, the $\mathrm{Cd}$ content was decreased and the $\mathrm{Cr}$ content was only slightly changed. The strong positive statistical relationship between soil $\mathrm{Zn}$ content and $\mathrm{Cu}, \mathrm{Pb}$ and $\mathrm{Ni}$ amount in seeds of chickpea was confirmed $(\mathrm{R}=0.799, \mathrm{R}=0.880, \mathrm{R}=0.951$, respectively). The negative linear statistical relationship between soil $\mathrm{Zn}$ content and $\mathrm{Cd}$ amount in seeds of chickpea was confirmed $(R=-0.774)$. Despite of decreased $C d$ content even in $D$ variant the determined $\mathrm{Cd}$ amount in chickpea seeds was by $20 \%$ higher than hygienic limit.

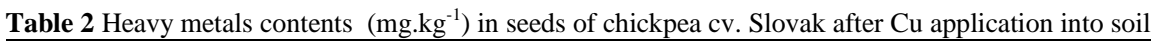

\begin{tabular}{|c|c|c|c|c|c|c|}
\hline Var. & $\mathrm{Zn}$ & $\mathrm{Cu}$ & $\mathrm{Ni}$ & $\mathrm{Cr}$ & $\mathrm{Pb}$ & $\mathrm{Cd}$ \\
\hline \multirow[b]{2}{*}{ A } & $\underline{37.50}$ & 7.35 & 1.08 & 1.23 & $\underline{0.45}$ & $\underline{0.05}$ \\
\hline & $\overline{(0.12)}$ & $(\overline{0.11})$ & $(\overline{0.08})$ & $(\overline{0.13})$ & $(\overline{0.05})$ & $(\overline{0.01})$ \\
\hline \multirow{2}{*}{ B } & $\underline{37.05}$ & $\underline{8.60}$ & $\underline{1.63}$ & $\underline{1.10}$ & $\underline{0.35}$ & $\underline{0.04}$ \\
\hline & $\overline{(0.11)}$ & $(\overline{0.10})$ & $(\overline{0.04})$ & $(\overline{0.07})$ & $(\overline{0.11})$ & $(\overline{0.01})$ \\
\hline \multirow{2}{*}{ C } & $\underline{37.88}$ & $\underline{9.05}$ & 2.13 & 1.23 & 0.25 & $\underline{0.10}$ \\
\hline & $(0.15)$ & $(0.17)$ & $(0.23)$ & $(0.08)$ & $(0.05)$ & $(0.01)$ \\
\hline \multirow[t]{2}{*}{ D } & $\underline{35.10}$ & $\underline{8.85}$ & $\underline{1.75}$ & $\underline{1.45}$ & $\underline{0.30}$ & 0.15 \\
\hline & $(0.12)$ & $(0.11)$ & (0.05) & $(0.11)$ & $(0.07)$ & $(0,03)$ \\
\hline Limit & 50.0 & 15.0 & 3.0 & 4.0 & 0.2 & 0.1 \\
\hline Max. & - & - & - & - & 0.2 & 0.1 \\
\hline
\end{tabular}

Legend: The results show the mean value and the standard deviation (in parenthesis). Limit value for legumes according to the Food Codex of the Slovakia was shown. Max. value is maximal residue level according to Commission Regulation 1881/2006. 
The determined contents of $\mathrm{Cu}, \mathrm{Pb}$ and $\mathrm{Zn}$ by Salama, Radwan (2005) in lenti and chickpea seeds were many times lower than those determined in our cultivar, and only $\mathrm{Cd}$ content determined by these authors was similar to our findings. Glowacka (2014) observed an interspecific facilitation between neighbouring plant species. Placement adjacent to the oat strip contributed to higher $\mathrm{Cu}$ content in the maize, while placement next to blue lupin increased the content of $\mathrm{Fe}$ and $\mathrm{Zn}$. This makes it possible to eliminate or mitigate mineral deficiencies in the plants.

\section{The total polyphenols content and antioxidant activity evaluation}

Total polyphenols (TP) content and antioxidant activity (AA) determined in chickpea cv. Slovak harvested in the stage of full ripeness are presented in Table 3 . The determined values of total polyphenol content ranged from $393 \mathrm{mg}$ GAE. $\mathrm{kg}^{-1}$ (Cu application) to $1215 \mathrm{mg}$ GAE. $\mathrm{kg}^{-1}$ ( $\mathrm{Zn}$ application). The determined values of antioxidant activity (as DPPH inhibition) were in interval $4.33 \%$ (Cu application) - $11.15 \%$ (Zn application).

Table 3 Total polyphenols content (mg.kg ${ }^{-1}$ ) and antioxidant activity (\% of DPPH inhibition)

\begin{tabular}{lcccc} 
Variant & Total polyphenol content & & Antioxidant activity \\
& Zn application & Cu application & Zn application & Cu application \\
\hline A & $742 \pm 10^{\mathrm{a}}$ & $672 \pm 10^{\mathrm{a}}$ & $10.32 \pm 1.60^{\mathrm{a}}$ & $4.80 \pm 0.90^{\mathrm{a}}$ \\
B & $1107 \pm 58^{\mathrm{b}}$ & $566 \pm 31^{\mathrm{b}}$ & $11.15 \pm 1.07^{\mathrm{b}}$ & $5.83 \pm 0.39^{\mathrm{b}}$ \\
C & $1215 \pm 46^{\mathrm{c}}$ & $574 \pm 66^{\mathrm{b}}$ & $9.33 \pm 1.04^{\mathrm{c}}$ & $4.93 \pm 0.80^{\mathrm{a}}$ \\
D & $661 \pm 24^{\mathrm{d}}$ & $393 \pm 12^{\mathrm{c}}$ & $5.77 \pm 1.50^{\mathrm{d}}$ & $4.33 \pm 0.53^{\mathrm{c}}$ \\
\hline
\end{tabular}

With increased $\mathrm{Zn}$ doses applied into the soil the TP contents established in seeds of chickpea cv. Slovak were increased. The maximal TP content in seeds of chickpea seeds harvested in the stage of full ripeness was found at 250-300 mg $\mathrm{Zn}$ applied into $1 \mathrm{~kg}$ of the soil while after application of higher $\mathrm{Zn}$ doses into the soil a lower TP content in seeds of this legume was observed. The strong statistical relationship was confirmed between $\mathrm{Zn}$ content in the soil and TP content $(\mathrm{R}=0.911)$ as well as AA values $(\mathrm{R}=0.992)$ in chickpea seeds.

With increased $\mathrm{Cu}$ doses applied into the soil the TP contents determined in seeds of chickpea cv. Slovak were decreased. The moderate statistical linear negative relationship between soil $\mathrm{Cu}$ content and TP content in seeds of chickpea cv. Slovak was confirmed $(\mathrm{R}=-0.671)$.

With increased $\mathrm{Cu}$ doses applied into the soil the AA values determined in seeds of chickpea cv. Slovak were only slightly changed. The moderate statistical linear positive relationship between soil $\mathrm{Cu}$ content and AA value in seeds of chickpea cv. Slovak was confirmed $(\mathrm{R}=0.621)$

Our values of polyphenols and antioxidant activity are although much lower than reported by $\mathbf{X u}$, Chang (2007). However, they are in partial agreement with other authors (Xu, Chang, 2008; Zia-Ul-Haq et al., 2008). The differences between results may be attributed to the differences in the sources of the samples.

\section{CONCLUSION}

The graded $\mathrm{Zn}$ doses applied into the soil in the model conditions resulted in increased $\mathrm{Zn}$ content in seeds of chickpea harvested in the stage of full ripeness. The strong statistical relationship between soil $\mathrm{Zn}$ content and $\mathrm{Zn}$ level in seeds of investigated chickpea cv. Slovak was confirmed.

With increased $\mathrm{Cu}$ doses applied into the soil the $\mathrm{Cu}$ contents determined in the fully rippened seeds of chickpea cv. Slovak were increased. The strong statistical relationship between soil $\mathrm{Cu}$ content and $\mathrm{Cu}$ amount in seeds was confirmed.

Graded $\mathrm{Zn}$ doses applied into the soil resulted in statistically significant increased $\mathrm{Pb}$ amounts and significantly decreased $\mathrm{Cd}$ amount in seeds of chickpea $\mathrm{cv}$. Slovak, whereas inverse relationship for graded $\mathrm{Cu}$ doses applied into the soi and those elements was observed (decreased $\mathrm{Pb}$ amounts, increased $\mathrm{Cd}$ amount). The determined $\mathrm{Pb}$ and $\mathrm{Cd}$ contents in seeds were higher than maximal allowed amounts given by the legislative. The contents of other tested heavy metals ( $\mathrm{Zn}$, $\mathrm{Cu}, \mathrm{Ni}, \mathrm{Cr}$ ) were lower than hygienic limits.

In experiment conditions, the total polyphenols contents determined in seeds chickpea cv. Slovak harvested in the stage of full ripeness were increased with soil enrichment with $\mathrm{Zn}$. Moreover, the strong statistical correlation between the content of $\mathrm{Zn}$ added into the soil and the antioxidant activity values was confirmed.

Graded $\mathrm{Cu}$ doses applied into the soil resulted in increased AA values in seeds of chickpea cv. Slovak harvested in the stage of full ripeness, whereas inverse relationship for TP content was observed.

Acknowledgement: The work was supported by grant VEGA No. 1/0308/14 from Ministry of Education, Slovak Republic.

\section{REFERENCES}

Aguilera, Y., Duenas, M., Estrella, I., Hernández, T., Benitez, V., Esteban, R.S., Martín-Cabrejas, M.A. (2011). Phenolic profile and antioxidant capacity of chickpeas (Cicer arietinum L.) as affected by a dehydration process. Plant Foods for Human Nutrition, 6 (2), 187-195. http://dx.doi.org/10.1007/s11130-0110230-8.

Ahlawat, I. P. S., Gangaiah, B., Ashraf, Z. M. (2007). Nutrient management in chickpea. In Yadav, S. S. et al. Chickpea breeding and management.
Wallingford, United Kingdom: CAB International, pp. 213-232. ISBN 9781 845932145.

Brand-Williams, W., Cuvelier, M. E., Berste, C. (1995). Use free radical method to evaluate antioxidant activity. LWT - Food Sci. Technol., 28 (1), 25-30.

Chau, C. F., Cheung, P. C., Wong, Y. S. (1997). Effect of cooking on content of amino acids and antinutrients in three chinese indigenous legume seeds. Journal of the Science of Food and Agriculture, 75 (4), 447-452. http://dx.doi.org/ 10.1002/(SICI)1097-0010.

Chibbar, R. N., Ambigaipalan, P., Hoover, R. (2010). Molecular diversity in pulse seed starch and complex carbohydrates and its role in human nutrition and health. Cereal Chemistry, 87 (4), 342-352. http://dx.doi.org/10.1094/CCHEM87-4-0342.

Dong, M. X., He, X., Liu, R. H. (2007). Phytochemicals of black bean seed coats: Isolation, structure elucidation and their antiproliferative and antioxidative activities. Journal of Agricultural and Food Chemistry, 55 (15), 6044-6051. http://dx.doi.org/10.1021/jf070706d.

Głowacka, A. (2014). Changes in the uptake of $\mathrm{Cu}, \mathrm{Zn}, \mathrm{Fe}$ and $\mathrm{Mn}$ by dent maize in blue lupin/spring oat strip cropping system. Zemdirbyste-Agriculture, 101 (1), 41-50. http://dx.doi.org/10.13080/z-a.2014.101.019.

Kamatou, G. P. P., Viljoen, A. M., Steenkamp, P. (2010). Antioxidant, antiinflammatory activities and HPLC analysis of South African Salvia species $\begin{array}{llll}\text { Food } \quad \text { Chemistry, } & 119 & \text { (2), } & \text { 684-688 }\end{array}$ http://dx.doi.org/10.1016/j.foodchem.2009.07.010.

Khan, H. R., MacDonald, G. K., Ryngel, Z. (1998). Assessment of the Zn status of chickpea by plant analysis. Plant and Soil, 198, 1-9. http://dx.doi.org/10.1023/A:1004289710069.

Lachman, J., Hejtmánková, A., Dudjak, E. (2003). Content polyphenolic antioxidants and phenolcarboxylic acids in selected parts of yacon. In Vitamin 2003 - Prírodní antioxidanty a volné radikály. Pardubice : University Pardubice, pp. 89-97. ISBN 80-7194-549-8.

Muzquiz, M., Wood, J. A. (2007). Antinutritional factors. In Yadav, S. S. et al. Chickpea breeding and management. Wallingford, United Kingdom: CAB International, pp. 143-166. ISBN 9781845932145

Roy, R. N., Finck, A., Blair, G. J., Tandon, H. L. S. (2006). Plant nutrition for food security. A guide for integrated nutrient management. FAO Fertilizer and Plant Nutrition Bulletin 16. Rome, Italy: Food and Agriculture Organization of the United Nations. 368 pp. ISBN 92-5-105490-8.

Rutkowska, B., Szulc, W., Łabętowicz, J. (2014). Zinc speciation in soil solution of selected Poland'agricultural soils. Zemdirbyste-Agriculture, 101 (2), 147-152. http://dx.doi.org/10.13080/z-a.2014.101.019.

Segev, A., Badani, H., Kapulnik, Y., Shomer, I., Oren-Shamir, M., Galili, S. (2010). Determination of polyphenols, flavonoids and antioxidant capacity in colored chickpea (Cicer arietinum L.). Journal of Food Science, 75 (2), S115 S119. http://dx.doi.org/10.1111/j.1750-3841.2009.01477.x.

Wang, N. , Hatcher, D. W., Tyler, R. T., Toewsa, R., Gawalko, E. J. (2010). Effect of cooking on the composition of beans (Phaseolus vulgaris L.) and chickpeas (Cicer arietinum L.). Research International, 43, 589-594. http://dx.doi.org/10.1016/j.foodres.2009.07.012.

Salama, A. K.,. Radwan, M. A. (2005). Heavy metals (Cd, Pb) and trace elements $(\mathrm{Cu}, \mathrm{Zn})$ contents in some foodstuffs from the Egyptian market. Emir. J. Agric Sci., 17 (1), 34-42. http://dx.doi.org/10.1016/j.foodchem.2009.07.010.

$\mathrm{Xu}$, B. J., Chang, S. K. C. (2007). A comparative study on phenolic profiles and antioxidant activities of legumes as affected by extraction solvent. J. Food Sci. 72, S159-S166. http://dx.doi.org/10.1111/j.1750-3841.2006.00260.x.

Xu, B. J., Chang, S. K. C. (2008). Effect of soaking, boiling, and steaming on total phenolic content and antioxidant activities of cool season food legumes. Food Chemistry, 110, 1-13. http://dx.doi.org/10.1016/j.foodchem.2008.01.045. 
Zia-Ul-Haq, M., Ahmad, M., Iqbal, S., Ahmad, S., Ali, H. (2007) Characterization and compositional study of oil from seeds of desi chickpea (Cicer arietinum L.) cultivars grown in Pakistan. J. Am. Oil Chem. Soc., 84, (12), 1143-1148. http://dx.doi.org/10.1007/s11746-007-1136-3

Zia-Ul-Haq, M., Iqbal, S., Ahmad, S., Bhanger, M. I., Wiczkowski, W., Amarowicz, R. (2008). Antioxidant potencial of desi chickpea varieties commonly consumed in Pakistan. Journal of Food Lipids, 15, 326-342. http://dx.doi.org/10.1111/j.1745-4522.2008.00122.x. 